\title{
Everyday Ethnocultural Adaptation of Newly Arrived and Indigenous Populations in Yugra
}

\author{
Boris Tkachev ${ }^{1}$, Igor Fedulov², Tatyana Moldanova², and Tatyana Tkacheva ${ }^{2}$ \\ ${ }^{1}$ Department of Economics, Yugra State University, 628012, Khanty-Mansiysk, Russia \\ ${ }^{2}$ Department of History, Philosophy and Law, Yugra State University, 628012, Khanty-Mansiysk, Russia
}

\begin{abstract}
This publication presents results of a study of everyday ethnocultural adaptation of newly arrived and indigenous populations in Khanty-Mansi Autonomous Okrug - Yugra. A survey has helped identify levels of frustration in newly arrived and indigenous populations. The authors have concluded that ethnocultural adaptation of newly arrived population is slow and patchy. The newly arrived population is more frustrated than the indigenous community is. To reduce the level of frustration, the newly arrived population needs to connect with ethnic customs and traditions of indigenous small numbered peoples of the North, understand how unique they are and ensure ethnic tolerance on both sides.
\end{abstract}

\section{Introduction}

At the turn of the XXI century, society faced a new phenomenon - the ethnic revival of indigenous small numbered peoples of the North. This process also affected the Western Siberian regions which are traditionally viewed as the "regions of the North of Russia" and are populated by both newly arrived and indigenous populations, with the latter classified as "small numbered peoples" due to the size of their communities. The North of Russia is currently a complex and contradictory mix of both integration and disintegration processes among the indigenous and newly arrived populations [1].

The issue of preserving cultural heritage of the world's peoples is quite pressing in today's society. In this regard, one of the most important challenges faced by the humanity is the search for efficient tools and procedures of preserving live cultural practices making up the foundation of the humanity's ethnocultural diversity that has been intensively shrinking due to the cultural globalization $[2,3]$.

\section{Methodology}

Everyday practice as a fundamental aspect of social reality was differently viewed and interpreted in various historic periods while its essential features underwent significant modifications. Everyday challenges have had a special place in foreign historic and cultural research and, over the last few decades, in the Russian science [48]. Scholars who study processes of ethnocultural adaptation are primarily interested in everyday practices because the latter represent an environment where said adaptation processes take place. Everyday activities that account for a major share of active lives of people involving a significant number of inter-ethnic contacts play a key role in adaptation mechanisms. On the other hand, ethnocultural adaptation is an important aspect in everyday practices that forms the ethnic image of peoples, as we know it thanks to inter-ethnic contacts.

Ethnocultural adaptation is a long-lasting, complex and comprehensive process affecting multiple aspects of people's lives. Both external, behavioral and internal, mental patterns undergo changes in the adaptation process. To define the process of ethnocultural adaptation, we presume that mental response to interethnic contacts determines behavioral patterns. In this case, the level of adaptation may be judged by the behavioral response to inter-ethnic interaction, e.g. by measuring the level of frustration in indigenous and nonindigenous populations.

Based on the above, the authors have formulated the objective of this research as: assessment of readiness to everyday ethnocultural adaptation in newly arrived and indigenous populations in Yugra. We selected the following methods to achieve the stated objective: 1 overt observation; 2 - structured interview; 3 - survey based on an ethnopsychological questionnaire; 4 - ethnic identification method proposed by V. S. Mukhina [9]. The following five types of potential behavior were taken into account while making the questionnaire:

1. Actively involved, adequately loyal, seeking to cope - positive, highest-level form of social normative response $\left(\mathrm{F}^{1}\right)$. This type was addressed with questions regarding the need to learn languages of indigenous peoples and the credibility of the indigenous population.

2. Actively involved, inadequately loyal, fixed on frustration - socially impaired (adaptive) positive form of response to frustration $\left(\mathrm{F}^{2}\right)$. This type was addressed

* Corresponding author: btkachev@ mail.ru 
with questions regarding showing initiative when getting acquainted and liking to be around indigenous or nonindigenous people, respectively.

3. Actively involved, adequately disloyal (aggressive), fixed on frustration - negative normative form of social response $\left(\mathrm{F}^{3}\right)$. This type was addressed with questions regarding unpleasant feelings when borrowing money, occasional boasting of ethnic identity, preferring to give no response when having an argument with indigenous or non-indigenous people, respectively.

4. Actively involved, adequately disloyal (ignoring), fixed on frustration - negative normative form of social behavior $\left(\mathrm{F}^{4}\right)$. This type was addressed with questions regarding the habit to say the first thing that springs to mind, or occasionally laugh at tasteless jokes about indigenous or non-indigenous people, respectively.

5. Passive, non-involved - socially impaired, nonadaptive form of response to frustration $\left(\mathrm{F}^{5}\right)$. This type was addressed with questions regarding feeling uncomfortable in ethnic clothing or in company with indigenous people, feeling uncomfortable about belonging to indigenous people, being concerned about miscommunication.

Research [1, 9-16] demonstrated that the evolution of ethnic identity depends on the existing context of interethnic interaction and nature of such interaction as affected by the social, political, economic and other factors. The underlying social crisis of an ethnic community contributes to negative inter-ethnic interaction, concern, tension, manifestation of marginal personal traits. On the other hand, purposeful productive activities form positive inter-ethnic relations. The indigenous small numbered peoples of the North tend to live in the context of century-old traditional lifestyles being under pressure from various factors: state institutions, newly arrived population, resource companies, etc. Overall, the size of indigenous Khanty and Mansi communities in Yugra is a dozen times smaller than that of the newly arrived population. Due to this fact, we started the survey with the expectation to find an elevated level of frustration in the indigenous population as compared to the newly arrived population.

In their paper, S. M. Pavlov and V.S. Mukhina (2001) determined that children of the indigenous small numbered peoples of the North manifest frustration, tension, concern, ethnic inferiority complex in a situation of inter-ethnic interaction [1].

Additionally, research conducted by the Department of Public and External Relations for the Khanty-Mansi Autonomous Okrug - Yugra in 2011-2013 [17] also confirmed tension among nationalities in Yugra (Fig. 1).

Based on the above, the working hypothesis to be verified in the course of the research was formulated as follows: the indigenous population manifests more frustration in the process of ethnocultural adaptation as compared to the newly arrived population.

The empirical base for the research included types of response to frustration from the indigenous people living in big cities of the region, smaller-size localities, ethnic settlements and nomad camps, and from non-indigenous people (differentiated by their experience in interacting with the indigenous small numbered peoples of the
North) who have lived in the region for 5 years and less, or for over 5 years. Each participant of the survey was attributed to the group of indigenous peoples by way of self-identification. In addition, we used the previously defined stratification of the ethnic community as the basis. The survey included more citizens from big cities, primarily Khanty-Mansiysk and Surgut. Determination of the adaptation period as equal to five years is quite relative; however, our research confirms this is the average period of social adaptation for the newly arrived population. It may also be related to the perception of their residence in the region as temporary due to being a student or being employed for seasonal and/or rotational work, or work based on a fixed-term contract when individuals do not see themselves living in Yugra in the future. The period of 5 (4-6) years may be indicative of this factor.

Stages of Research. There have been three stages of studying the everyday ethnocultural adaptation. At the first stage, in 2011-2017, we studied characteristics of everyday lifestyles and routine of the indigenous small numbered peoples of the North, their cultural characteristics as compared to the newly arrived population [10,11]. At the second stage (in 2017), based on the previously collected and analyzed data, we developed a survey for the newly arrived and indigenous populations to be used to determine their level of frustration. Finally, at the third stage (in 2018) we conducted the survey which we intend to continue conducting in the subsequent years.

\section{Results and Discussion}

We have analyzed a total of 339 questionnaires: 188 questionnaires filled out by the non-indigenous people, with 117 among them having experience in interacting with the indigenous small numbered peoples of the North and 71 among them having no such experience. The number of participants from among the indigenous small numbered peoples of the North was 151 . We used the "Eysenck Personality Inventory" (EPI) [18] as the basis for the questionnaire comprising 20 questions. The questionnaire was drafted in two versions: for the indigenous and non-indigenous populations. The differences regarded the wording of certain questions touching upon ethnic and cultural identity of the indigenous small numbered peoples of the North and of the newly arrived population. To identify the types of response to frustration, questions were grouped by five types of potential participant behavior. The questionnaires were processed; percentage-wise, answers characterize each group of Yugra's population with regard to the type of response to frustration. The questionnaire also includes the social adaptation scale that demonstrates to what extent the participant attempts to adapt answers to the socially accepted and encouraged views and, consequently, to what extent these answers may be wrong or distorted. The results are listed in Table 1.

The survey demonstrated that using a questionnaire allows for identification of types of response to 
frustration in newly arrived and indigenous populations. However, the level of frustration is only similar between indigenous population living in nomad camps and nonindigenous population. In other groups of indigenous population, the level of frustration is lower. This phenomenon may be explained by the fact that the indigenous people who have lived close to the newly arrived population for a few generations has been included in the process of ethnocultural adaptation for a long time now, in comparison to the population that has been isolated in nomad camps and ethnic settlements. We believe that in this case the key reason for the low level of frustration lies with the significantly lower frequency of inter-ethnic contacts in the described living conditions due to the pronounced ethnocultural characteristics that manifest themselves in peculiar stereotypes of behavior and lead to the isolation from the newly arrived population.

It is interesting to note a more than two-fold difference in the number of survey participants from among indigenous and non-indigenous people as regards the first type of behavior. In our view, it could be explained by the following: the indigenous population is by far more open to the contacts with the newly arrived population, possibly due to a higher level of "cultural" interest. Doctors, teachers, highly qualified specialists were all initially from among the newly arrived population. Those indigenous people who became educated and gained a qualification were in contact with the non-indigenous population for a long time and became partially adapted. Types of behavior form over multiple generations; this is a relatively lengthy process.

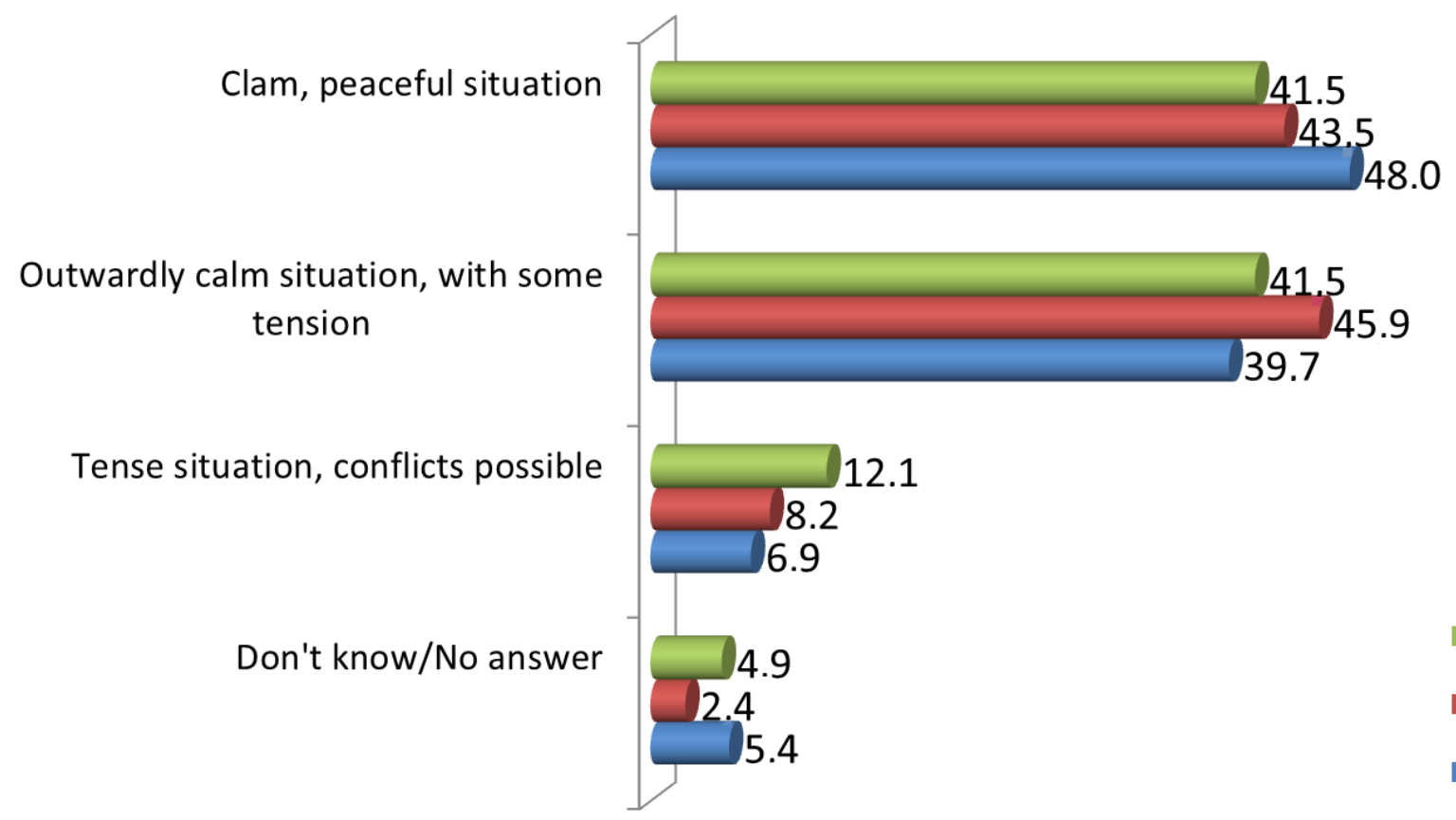

2013

2012

2011

Fig. 1. Assessment of inter-ethnic relations in the locality one lives in [14].

Table 1. Level of frustration among Yugra's population.

\begin{tabular}{|c|c|c|c|c|c|}
\hline \multirow[t]{2}{*}{ Groups of population } & \multicolumn{5}{|c|}{ Types of response to frustration (\%) } \\
\hline & $\mathrm{F}^{1}$ & $\mathrm{~F}^{2}$ & $\mathrm{~F}^{3}$ & $\mathrm{~F}^{4}$ & $\mathrm{~F}^{5}$ \\
\hline $\begin{array}{l}\text { Non-indigenous population having experience in interacting with the } \\
\text { indigenous small numbered peoples of the North and living in Yugra } \\
\text { for over } 5 \text { years }\end{array}$ & 9.0 & 30.0 & 23.0 & 25.0 & 13.0 \\
\hline $\begin{array}{l}\text { Non-indigenous population having experience in interacting with the } \\
\text { indigenous small numbered peoples of the North and living in Yugra } \\
\text { for less than } 5 \text { years }\end{array}$ & 6.0 & 30.0 & 27.0 & 23.0 & 14.0 \\
\hline $\begin{array}{l}\text { Non-indigenous population having no experience in interacting with } \\
\text { the indigenous small numbered peoples of the North and living in } \\
\text { Yugra for over } 5 \text { years }\end{array}$ & 8.0 & 19.5 & 30.5 & 19.0 & 23.0 \\
\hline $\begin{array}{l}\text { Non-indigenous population having no experience in interacting with } \\
\text { the indigenous small numbered peoples of the North and living in } \\
\text { Yugra for less than } 5 \text { years }\end{array}$ & 8.5 & 30.0 & 27.0 & 20.5 & 14.0 \\
\hline Indigenous population from nomad camps & 11.5 & 28.5 & 28.5 & 23.5 & 8.0 \\
\hline Indigenous population from ethnic settlements & 15.0 & 27.0 & 27.5 & 15.5 & 15.0 \\
\hline Indigenous population from Yugra's smaller-size localities & 18.0 & 30.0 & 18.0 & 18.0 & 16.0 \\
\hline Indigenous population from Yugra's big cities & 15.5 & 31.0 & 25.0 & 16.0 & 12.5 \\
\hline
\end{tabular}


The research has discovered an interesting phenomenon: a part of the non-indigenous population is not included in the adaptation process. Due to the small size of the indigenous community, the newly arrived population (even from among the long-term residents) has no or a very poor idea of the problems faced by the indigenous community and very often has a neutral response to these problems.

Therefore, we have to acknowledge that the working hypothesis of the indigenous population having a higher level of frustration as compared to the non-indigenous population could not been confirmed.

\section{Conclusion}

The process of ethnocultural adaptation among the newly arrived population is slow and patchy. The newly arrived population is more frustrated than the indigenous community. In terms of loyalty, the indigenous small numbered peoples of the North are also clearly ahead of the newly arrived population. The reason is that the adaptation problems are more pressing for the indigenous small numbered peoples of the North since, unlike the newly arrived nationalities, they have to adapt to both universal drastic political, social, economic and cultural changes and to the new linguistic situation, changes in attitude from the newly arrived population (with long-term Russian residents being more involved in the process of ethnocultural adaptation as compared to the new residents), etc.

The willingness of the indigenous people to see a higher level of ethnocultural adaptation in the newly arrived population has been for decades counteracted by the temporary nature of residence of the newly arrived population. It was only in mid-1990's that there appeared a trend for the newly arrived population to take a foothold in the region which was further supported by the drastic reduction in the number of migrants in these recent years.

To bring down the level of frustration, we need to employ procedures that could encourage ethnocultural tolerance among the newly arrived and indigenous populations which also requires identification of social and psychological aspects of mutual perception in everyday contacts, study of the existing intercultural areas of comfort and conflict, discovery of factors that could form a local, culturally universal identity via connecting the newly arrived population to the historical and cultural heritage of the indigenous peoples of the area, among other things.

\section{References}

1. S. M. Pavlov, V.S. Mukhina, Personality Development 3-4, 55-75 (2001)

2. Yu. S. Zamarayeva, International Journal of Applied and Fundamental Research 5, 113-116 (2014)

3. V. A. Tishkov, V. V. Stepanov (ed.), Ethnopolitical situation in Russia and neighboring states in 2011. Annual report by the Network of ethnic monitoring and early conflict prevention, (Institute of Ethnology and Anthropology, Russian Academy of Science, Moscow, 2012)

4. N. O. Kozlova, Social sciences and the modern era 3 (1992)

5. A. V. Khudenko, Sotsis 4, (1993)

6. R. P. Shulga, Art in the world of mundane consciousness (Naukova Dumka, Kyiv, 1993)

7. V. N. Gorelova, Mundane consciousness as a philosophical problem (Perm, 1993)

8. L. G. Ionin, Sociology of culture: journey to the new millennium (Logos, Moscow, 2000)

9. V.S. Mukhina, Phenomenology of personality development and existence (MPSI: MODEK, Moscow-Voronezh, 1999)

10. T. A. Moldanova, "We're still giving birth therefore we exist!" Khanty ethnic identity today, From the Volga to Siberia. The Finno-Ugric Peoples in Today's Russia, 46-55 (Helsinki, 2012)

11. T. A. Moldanova, Bulletin of Ugric Studies 4, 131143 (2017)

12. R. Jenkins, Ethnic and Racial Studies 17(2), 197223 (2004)

13. T. I. Troshina, O. M. Morozova, Ethnographic Review, 6, 93-110 (2017)

14. A. Ventsel, Bruchlinien im Eis: Ethnologie des zirkumpolaren Norden 1, 17-30 (Lit-Verlag: Wien, Schriftenreihe: Beiträge zum zirkumpolaren Norden, 2005)

15. M. Sökefeld, Anthropos 96 (2), 527-544 (2001)

16. Marjorie M. Balzer, The Tenacity of Ethnicity: A Siberian Saga in Global Perspective (Princeton University Press, Princeton, 1999)

17. Inter-ethnic and inter-confessional relations in the Khanty-Mansi Autonomous Okrug - Yugra, Department of Public and External Relations for the Khanty-Mansi Autonomous Okrug - Yugra, List of sociological research in Yugra (2013)

18. Eysenck Personality Inventory (EPI Temperament Inventory, Eysenck Self-Assessment Diagnostics. Temperament appraisal methodology), Psychology of a happy life 